\title{
DETEKSI DINI TUBERKULOSIS SEBAGAI UPAYA PENCEGAHAN PENULARAN PENYAKIT TUBERKULOSIS DAN PENGOLAHAN HERBAL ANTITUBERKULOSIS BERBASIS RISET
}

\author{
Sri Agung Fitri Kusuma ${ }^{1}$, Toto Subroto ${ }^{2}$, Ida Parwati ${ }^{3}$ dan Tina Rostinawati ${ }^{1}$ \\ ${ }^{1}$ Departemen Biologi Farmasi, Fakultas Farmasi, Universitas Padjadjaran; \\ ${ }^{2} J u r u s a n$ Kimia, Fakultas Matematika dan Ilmu Pengetahuan Alam, \\ ${ }^{3}$ Fakultas Kedokteran, Universitas Padjadjaran, Jatinangor, Jawa Barat, Indonesia \\ E-mail: s.a.f.kusuma@unpad.ac.id
}

\begin{abstract}
ABSTRAK. Pengetahuan masyarakat yang tepat tentang gejala tuberkulosis dapat dijadikan sebagai strategi deteksi dini untuk dapat mempercepat tindakan pemeriksaan dan pengobatan sehingga dapat mencegah penularan tuberkulosis akibat keterlambatan diagnosis. Tujuan dari kegiatan penyuluhan ini adalah untuk mencegah penularan tuberkulosis melalui peningkatan pengetahuan masyarakat desa Cilayung Jatinangor tentang gejala tuberkulosis secara dini, memupuk kesadaran masyarakat untuk memutuskan rantai penularan melalui pemeriksaan dini dan pengobatan yang cepat dan tepat serta mengenalkan hasil riset berupa herbal anti tuberkulosis yang dapat diolah secara mandiri sebagai pengobatan alami. Kegiatan ini meliputi pengumpulan data informatif pengetahuan masyarakat tentang penyakit tuberkulosis melalui wawancara dan pre-test, dilanjutkan dengan kegiatan penyuluhan, post test, pengenalan herbal antituberkulosis dan teknik pengolahannya. Hasil yang diperoleh adalah didapatkan data tingkat pengetahuan masyarakat desa Cilayung tentang penyakit tuberkulosis dan pengenalan gejala tuberkulosis secara dini yaitu sebanyak $6.67 \%$ berpengetahuan baik, $23.3 \%$ berpengetahuan cukup, dan $70 \%$ berpengetahuan kurang. Jadi dapat disimpulkan bahwa setelah diadakan penyuluhan, tingkat pengetahuan warga meningkat menjadi $16,67 \%$ berpengetahuan baik, $56,67 \%$ berpengetahuan cukup, dan $26,67 \%$ berpengetahuan kurang. Teknik pengolahan herbal antituberkulosis menjadi bentuk sediaan teh celup dan serbuk instan, yang mengandung herba sambiloto (Andrographis paniculata (Burm. F) Ness), herba pegagan (Centella asiatica), daun beluntas (Pluchea indica) dan rimpang kencur (Kaempferia galanga L.) diharapkan dapat memudahkan masyarakat Cilayung dalam pengobatan swamedikasi melalui pemanfaatan tanaman herbal yang efektif, mudah didapat dan murah.
\end{abstract}

Kata kunci: Cilayung; tuberkulosis; deteksi; sambiloto; pegagan; kencur; beluntas

ABSTRACT. The appropriate knowledge of the community about the tuberculosis symptoms can be used as an early detection strategy to accelerate the tuberculosis examination and treatment, thus the transmission of tuberculosis due to late diagnosis, can be prevented. The purpose of these outreach activities were to prevent the transmission of tuberculosis by increasing the knowledge of the Cilayung Jatinangor people on the early symptoms of tuberculosis, fostering public awareness to break the chain of transmission, and provide the knowledge of appropriate treatment for tuberculosis using common tuberculosis drugs and studied herbal drug. The methods of these activities were consisted of the collection of informative data on community knowledge about tuberculosis through interviews and pre-tests, followed by counseling activities, post-tests, introduction of antituberculosis herbs and processing techniques. From the pre-test results, the obtained data on the level of knowledge of the Cilayung villagers about tuberculosis and early tuberculosis symptom recognition were $6.67 \%$ knowledgeable, $23.3 \%$ knowledgeable enough, and $70 \%$ lacking knowledge. Thus, it can be concluded that after counseling, the knowledge level of Cilayung people increased and the results were $16.67 \%$ of knowledgeable, 56.67\% of knowledgeable enough, and $26.67 \%$ of less knowledgeable. The processing techniques of antituberculosis herbal into instant tea bags and powder preparations containing herbs of sambiloto (Andrographis paniculata (Burm. F) Ness), pegagan (Centella asiatica), beluntas (Pluchea indica) and kencur rhizomes (Kaempferia galanga L.) were expected can facilitate the Cilayung community in self-medication treatment through the use of effective, easily available and inexpensive herbal plants

Key words: Cilayung; tuberculosis; detection; Andrographis paniculata; Centella asiatica; Kaempferia galanga L; Pluchea indica

\section{PENDAHULUAN}

Tuberkulosis adalah salah satu penyakit infeksi yang penyakit yang disebabkan oleh Mycobacterium tuberculosis dan dilaporkan sebagai salah satu penyebab tertinggi di dunia [Todar, 2012; Romero et al., 2011]. Menurut World Health Organization (WHO), pada tahun 2008 terdapat kurang lebih 9,4 juta kasus di seluruh dunia, dengan 1,8 juta kematian, dan dilaporkan terjadi 4.500 kematian perharinya [WHO, 2009]. Indonesia merupakan negara ke-3 terbanyak di dunia setelah India dan Cina, yang memiliki pasien TBC, dengan jumlah pasien sekitar 10\% dari total jumlah pasien tuberkulosis di dunia. Insidensi kasus tuberkulosis Basil Tahan Asam positif sekitar 110 per 100.000 penduduk [Retno, 2011; Murray et al., 1990].
Saat ini peningkatan kasus tuberkulosis sejalan dengan peningkatan kasus tuberkulosis yang resis-ten terhadap antibiotika khususnya di negara berkembang termasuk Indonesia. Para peneliti memperkirakan \pm 50 juta orang terinfeksi galur M. tuberculosis yang resisten terhadap paling tidak satu macam Obat Anti Tuberculosis (OAT). Resistensi M. tuberculosis terhadap antibiotika seperti INH/isoniazid, streptomisin, etambutol, rifampisin, dapat disebabkan oleh beberapa hal, antara lain pengobatan yang tidak teratur dan ketidakpatuhan berobat [Morris et. al., 1995]. Kemungkinan munculnya strain yang lebih tahan terhadap antibiotik sangat besar untuk terjadi di kemudian hari [Damma et al., 2009]. Munculnya galur bakteri $M$. tuberculosis yang diketahui resisten terhadap beberapa antibiotik tersebut, akan semakin memperparah 
kondisi penderita karena pengobatan yang tidak efektif lagi.

Kejadian tuberkulosis yang paling sering terjadi adalah tuberkulosis paru yang ditandai oleh gejala-gejala khas seperti batuk selama 2 minggu atau lebih disertai sesak nafas, berkeringat malam hari, dan batuk darah. Jika dibiarkan tanpa pengobatan, tuberkulosis paru dapat menyebar menyerang organ-organ lain dan juga dapat menyebabkan kematian [Kemenkes RI, 2009]. Penyakit ini mudah menyebar di udara ketika orang-orang yang sakit dengan tuberkulosis paru melepaskan bakteri melalui mekanisme batuk sehingga orang di sekitar pasien dapat dengan mudah terinfeksi [WHO, 2016]. Penegakkan diagnosis tuberkulosis yang cepat dan akurat dapat dijadikan solusi permasalahan keterbatasan metode deteksi tuberkulosis yang mengakibatkan keterlambatan pengobatan tuberkulosis.

Kepadatan penduduk tersebut merupakan salah satu faktor penting yang harus diwaspadai dalam penyebaran penyakit tuberkulosis. Desa Cilayung merupakan desa yang terletak di Kecamatan Jatinangor dengan tingkat kepadatan penduduk yang cukup tinggi yaitu 5321 jumlah penduduk tercatat. Dengan demikiana, pengetahuan deteksi dini terhadap tuberkulosis sangat membantu mencegah penularan tuberkulosis di desa Cilayung. Saat ini, salah satu program kesehatan yang menjadi sasaran pemerintah Indonesia adalah pemberantasan tuberkulosis melalui program pengobatan gratis di semua puskesmas. Selain mewaspadai gejala tuberkulosis yang terjadi pada diri pribadi dan masyarakat sekitar melalui pengenalan gejala tuberkulosis secara dini, diperlukan juga serangkaian tes untuk menegakkan diagnosis tuberkulosis.

Menurut International Standard of Tuberculosis Care, golden standard pemeriksaan tuberkulosis adalah pemeriksaan dahak dengan atau tanpa rontgen. Bila, pemeriksaan dahak tidak dapat dilakukan, maka rontgen juga dapat menjadi alat diagnostik tuberkulosis. Sedangkan, tes Mantoux saat ini, dipakai pada anak untuk memperhatikan klinis dengan memakai sistem skoring. Penggunaan tes Mantoux pada dewasa untuk diagnostik tuberkulosis sebaiknya tidak digunakan. Karena, pemeriksaan serologi untuk tuberkulosis, nilai sensitifitasnya rendah. Selain itu, tes darah juga perlu dilakukan untuk membantu diagnosa tuberkulosis. Pencegahan dan pengobatan dini dapat mengurangi biaya pengobatan dan perawatan tuberkulosis serta berdampak tinggi bagi kehidupan dan kelayakan penderita.

Bagi masyarakat desa khususnya, dengan jarak yang cukup jauh antara rumah tinggal terhadap puskesmas atau tempat pelayanan kesehatan, maka diperlukan pertimbangan pengobatan dengan bahan obat yang mudah dijangkau. Program pengabdian yang berintegrasi dengan hasil riset merupakan mediator efektif dalam peningkatan ilmu terkait pengobatan dan aplikasinya di masyarakat. Beberapa tanaman yang telah diteliti sebagai antibiotik alami tuberkulosis, diantaranya adalah herba sambiloto
(Andrographis paniculata (Burm. F) Ness), herba pegagan (Centella asiatica), daun beluntas (Pluchea indica) dan kencur (Kaempferia galanga L.). Seluruh herbal tersebut mampu menghambat pertumbuhan $M$. tuberculosis $\mathrm{H} 37 \mathrm{Rv}$ sebesar 100\% pada masing-masing konsentrasi sebagai berikut: herba sambiloto $(5 \mathrm{mg} / \mathrm{mL})$, herba pegagan $(5 \mathrm{mg} / \mathrm{mL})$, daun beluntas $(5 \mathrm{mg} / \mathrm{mL})$ dan kencur (1 mg/mL) [Radji, et al., 2015; Fauziyah PN, et al., 2017]. Teknik pengolahan herbal tersebut dapat dilakukan dengan beberapa tahap yang harus diinformasikan dengan baik dan jelas kepada masyarakat desa Cilayung. Dengan mempertimbangkan bagian tanaman, rasa dan kemudahan pengolahan, maka dapat dipilih beberapa bentuk sediaan, seperti teh (daun beluntas, herba pegagan, sambiloto) dan serbuk instan (kencur). Dengan pengetahuan gejala tuberkulosis, masyarakat mampu melakukan deteksi dini dan segera menindaklanjuti penyakitnya ke tempat pelayanan kesehatan terdekat untuk diperiksa dan diobati. Hal ini akan sangat membantu program pemberantasan tuberkulosis yang dicanangkan Pemerintah. Selain itu, masyarakat desa Cilayung diharapkan dapat mengolah produk herbal tuberkulosis alami secara mandiri dengan baik dan benar.

\section{METODE}

Metode pelaksanaan Pengabdian Pada Masyarakat (PPM) Integratif ini meliputi: pengarahan program PPM dan tahapan serta target yang ingin dicapai kepada tim pelaksana dan mahasiswa KKN, perizinan dan sosialisasi program PPM serta diskusi tentang program PPM yang akan dilaksanakan kepada Kepala Desa Cilayung, aparat desa dan Kader PKK. Pada tahap ini, dihasilkan integrasi program desa dan PPM agar dihasilkan suatu output yang dapat diterima dan diterapkan dengan baik pada masyarakat desa Cilayung. Pelaksanaan program PPM meliputi tahapan wawancara, pre-test, penyuluhan, post test, pelatihan, dan evaluasi.

Wawancara yang dilakukan bertujuan untuk memperoleh data keseharian penduduk, kebersihan lingkungan, dan tingkat pengetahuan penduduk terkait penyakit tuberkulosis, sehingga dapat menunjang penyuluhan yang akan dilaksanakan selanjutnya. Tim pelaksana dibantu dengan tim mahasiswa KKNM melaksanakan pre-test tentang tuberkulosis terhadap 30 orang warga Desa Cilayung.

Tujuan pre-test ini adalah untuk mengetahui tingkat pengetahuan responden terhadap penyakit tuberkulosis, penyebab, gejala, penularan, pencegahan, resiko ketidakpatuhan mengkonsumsi obat tuberkulosis dan etika batuk. Informasi yang diperoleh dari kegiatan wawancara dan pre-test dijadikan acuan materi penyuluhan terkait tuberkulosis.

Metode penyuluhan yang digunakan berupa metode ceramah dan diskusi, dilengkapi dengan pembagian leaflet penyakit tuberkulosis. Program penyuluhan ini bertujuan 
memberikan pengetahuan terkait penyakit tuberkulosis terutama pengenalan gejala penyakit sebagai dasar awal deteksi dalam mengskrining penderita tuberkulosis. Dengan mengetahui gejala, maka setiap individu akan lebih waspada dengan penyebaran penyaki tuberkulosis. Untuk itu, salah satu materi penyuluhan yang penting juga ditekankan kepada resiko individu untuk terkena tuberkulosis. Pada penyuluhan ini, setiap individu juga diajarkan tentang pencegahan dan pengobatan, baik menggunakan obat sintesis dan herbal alami. Masyarakat pun diberikan informasi terkait pengobatan sintesis yang harus disertai dengan kepatuhan dan keteraturan sehingga dapat mencapai pengobatan yang efektif. Sedangkan untuk penggunaan herbal alami, diinformasikan bahwa penggunaannya tidak pada waktu yang sama dengan obat sintesis yang digunakan, diperlukan jeda waktu.

Kegiatan post-test ini bertujuan untuk mengevaluasi pemahaman dan pengetahuan masyarakat desa Cilayung tentang penyakit tuberkulosis, terutama deteksi dini tuberkulosis. Oleh karena itu, jenis pertanyaan yang diajukan dalam post test sama dengan pre-test.

Kegiataninibertujuanuntukmengenalkanmasyarakat pada bentuk sediaan herbal yang diketahui mengandung senyawa alami yang dapat menghambat $M$. tuberculosis dan pengolahan herbal dengan cara yang benar sehingga dapat menghasilkan produk herbal bermutu dan aman digunakan masyarakat. Teknik pengolahan herbal harus diawali dengan pengetahuan yang benar tentang setiap tahap pengolahannya, mulai dari tahap penyortiran, pencucian, penirisan, pengeringan, penyimpanan dan pengolahan. Dalam menjaga kualitas mutu bahan herbal, penyortiran bahan herbal merupakan teknik awal yang penting untuk dilakukan. Terutama untuk herbal jenis rimpang, seperti kencur. Rimpang kencur disortir berdasarkan kondisi rimpang yamng masih baik kondisinya dipisahkan dengan yang sudah membusuk. Demikian pula dengan tanah dan gulma yang melekat pada rimpang, harus dibersihkan terlebih dahulu. Hal serupa dilakukan untuk tanaman obat yang diambil daun, maupun herba, seperti daun beluntas, daun pegagan dan herba sambiloto. Setelah itu, dilakukan pencucian bahan herbal. Tujuan pencucian adalah untuk membersihkan bahan herbal dari kotoran yang mungkin masih melekat pada bahan sehingga dapat menjaga kualitas mutu bahan herbal. Setelah cuci, herbal direndam dalam air bersih terlebih dahulu, namun tidak boleh terlalu lama, karena ada kemungkinan zat-zat tertentu dapat larut dalam air sehingga mempengaruhi kualitas herbal. Kemudian herbal dicuci sambil disikat menggunakan sikat yang halus dan air bersih yang mengalir. Penyikatan ini menjadi bagian penting dari proses pencucian, terutama pada herbal rimpang yang bentuknya berlekuk, sehingga tanah cenderung melekat kuat pada daerah lekukan rimpang tersebut. Sedangkan untuk bahan herbal berupa dedaunan dan herba, pencucian cukup dilakukan dengan menggunakan teknik perendaman dan pencucian dengan air mengalir. Setelah dicuci, herbal ditiriskan dan dikeringkan. Tujuan pengeringan adalah untuk mengeluarkan atau menghilangkan air dari suatu bahan dengan bantuan sinar matahari, sehingga dapat disimpan dalam jangka waktu lama sebagai simplisia, memudahkan pengangkutan, dan memberikan aroma herbal yang khas. Bahan herbal dapat dikeringkan dengan meletakkannya pada rak pengering atau para, atau dapat juga dengan cara ditutupi menggunakan kain hitam, kemudian dikeringkan di bawah sinar matahari atau menggunakan alat. Pengeringan bahan herbal dilakukan hingga diperoleh massa herbal yang sudah memiliki bobot konstan dan dapat diremas kering dengan mudah. Simplisia yang dihasilkan dapat diolah lebih lanjut menjadi berbagai bentuk sediaan seperti: serbuk instan, teh, minyak atsiri, ekstrak, ekstrak kering maupun kapsul. Simplisia dikemas untuk disimpan, menggunakan bahan pengemas yang tidak beracun atau tidak bereaksi dengan bahan simplisia, seperti: jala plastik, kertas atau karung goni. Setiap kemasan tersebut harus diberi label yang memuat informasi sebagai berikut: nama bahan, bagian tanaman yang digunakan, no/kode produksi, berat bersih dan nama/alamat penghasil. Ruang penyimpanan yang digunakan pun harus memenuhi persyaratan yaitu bersih, ventilasi udara cukup baik, tidak bocor, suhu gudang $\left(<30^{\circ} \mathrm{C}\right)$, kelembaban udara $(<65 \%)$ dan bebas dari hewan. Pada PPM ini, bahan herbal yang diolah menajdis ediaan anti tuberkulosis adalah herba sambiloto $(5 \mathrm{mg} / \mathrm{mL})$, herba pegagan $(5 \mathrm{mg} / \mathrm{mL})$, daun beluntas $(5 \mathrm{mg} / \mathrm{mL})$ dan kencur $(1 \mathrm{mg} / \mathrm{mL})$.

Bahan herbal yang diolah menjadi teh herbal adalah simplisia herba sambiloto, herba pegagan, dan daun beluntas. Masing-masing simplisia diblender kasar atau digerus manual, kemuadia disaring dengan mesh ukuran 40. Kemudian masing-masing serbuk herbal tersebut ditimbang sebanyak 2 gram dan dikemas dalam kantong teh celup. Penggunaan teh celup herbal tersebut dilakukan dengan diseduh menggunakan air panas suhu $95{ }^{\circ} \mathrm{C}$ sebanyak $200 \mathrm{~mL}$ selama 5 menit sambil diaduk. Saat penyajiannya, teh herbal ini dapat ditambahkan dengan madu atau gula dengan tingkat kemanisan sesuai selera.

Simplisia kencur diblender halus dan dikemas dalam kantong atau wadah tertutup rapat. Dalam penyajiannya, serbuk kencur sebanyak 1 gram atau sekitar satu sendok teh diambil dan diseduh dengan air panas sebanyak 200 $\mathrm{mL}$. Untuk menambah rasa, minuman kencur ini dapat disajikan dengan penambahan gula sesuai selera.

\section{HASIL DAN PEMBAHASAN}

Program Pengabdian Masyarakat Prioritas integratif ini dilaksanakan oleh tim pelaksana PPM yang berasal dari beberapa Fakultas dengan kompetensi sinergis dengan topik PPM sehingga dapat mendukung keberhasilan pencapaian target PPM. Kerjasama yang terjalin antara tim pelaksana, aparat desa, masyarakat setempat dan mahasiswa KKN memberikan kontribusi nyata dalam kelancaran pelaksanaan kegiatan pengabdian masyarakat di desa Cilayung. 
Peranan aparat desa dan kader sangat penting dalam menentukan rumusan masalah dan sasaran kelompok target. Mengingat topik pengabdian ini adalah berkaitan dengan penyakit tuberkulosis, maka kelompok sasaran yang dipilih adalah kader posyandu dan masyarakat setempat. Berdasarkan hasil diskusi dengan aparat dan kader desa, diketahui bahwa sarana kesehatan desa Cilayung terletak cukup jauh dari lokasi desa, yaitu di daerah Jatinangor. Jenis layanan kesehatan Di Cilayung sebagai berikut:polindes(Balita dan ibu hamil), puskesmas Jatinangor, puskesmas Kencana, puskesmas Medika, puskesmas Padjadjaran, Rumah Sakit AMC dan Rumah Sakit Kabupaten. Diantara layanan kesehatan tersebut, jarak terdekat adalah dengan puskesmas Jatinangor. Hal ini cukup menarik untuk dijadikan sasaran penyuluhan karena jauhnya sarana pelayanan kesehatan mengharuskan masyarakat desa untuk mampu mewaspadai gejala suatu penyakit dan memberikan pengobatan mandiri sebagai pertolongan pertama.

Terkait dengan data penderita tuberkulosis, tidak terdapat informasi secara kuantitatif tentang jumlah penderita. Namun dilaporkan, telah ada beberapa penduduk yang menderita tuberkulosis dan beberapa memiliki kemiripan gejala yaitu batuk yang tak kunjung sembuh selema berbulan-bulan. Informasi ini pun sangat menunjang pentingnya dilakukan penyuluhan kesehatan tentang tuberkulosis, sehingga masing-masing invidu dapat mewaspadai resiko penularan yang dapat terjadi dengan tanpa disadari. Dengan demikian, pemberian informasi mengenai deteksi awal tuberkulosis dapat dengan mudah diberikan melalui penyuluhan sehingga masyarakat dapat melakukan pencegahan dan pengobatan secara mandiri setelah mengetahui gejala tuberkulosis dengan benar. Hal ini merupakan salah satu nilai tambah dari kegiatan ini mengingat bahwa sumber informasi IPTEK Desa Cilayung adalah sebagai berikut: tidak ada Warnet (Warung Internet), akses internet mandiri (dari smartphone), melalui Televisi, smartphone dan adanya Perpustakaan di Wilayah Citeureup yang jaraknya $\pm 3 \mathrm{~km}$ dari Desa Cilayung.

Pentingnya dilakukannya penyuluhan tentang penyakit tuberkulosis juga diperkuat dengan adanya hasil wawancara dengan masyarakat setempat. Dari setiap kepala keluarga, tim mendapatkan data pengetahuan warga tentang penyakit tuberkulosis dan apakah warga menggunakan obat herbal sebagai penanganannya. Dari wawancara tersebut, dapat dianalisa pula gambaran keseharian penduduk, kebersihan lingkungan, dan tingkat pengetahuan penduduk terkait penyakit tuberkulosis, sehingga dapat menunjang kesesuaian materi penyuluhan yang akan dilaksanakan selanjutnya.

Selain dari data wawancara, hal yang melatarbelakangi topik penyuluhan tentang tuberkulosis adalah berdasarkan hasil pre-test yang dijalani oleh 30 responden masyarakat di Desa Cilayung yang dilakukan oleh tim pelaksana dan mahasiswa KKNM. Pre-test tersebut telah disusun disesuaikan dengan penilaian tingkat pengetahuan yang telah dibuat. Teknis pre-test yaitu dengan cara door to door kepada 30 warga yang sebelumnya telah diwawancara. Hasil pre-test yang diperoleh adalah didapatkan data tingkat pengetahuan masyarakat desa Cilayung tentang penyakit tuberkulosis dan pengenalan gejala tuberkulosis secara dini yaitu sebanyak $6.67 \%$ berpengetahuan baik, $23.3 \%$ berpengetahuan cukup, dan $70 \%$ berpengetahuan kurang. Beberapa pengetahuan terkait tuberkulosis tidak dapat dijawab dengan benar oleh para responden, diantaranya adalah gejala tuberkulosis dan perbedaannya dengan batuk biasa, pengobatan, alasan kepatuhan pengobatan, cara penularan, pencegahan dan pengetahuan umum tentang herbal yang dapat dimanfaatkan untuk tuberkulosis secara empiris.

Berdasarkan data survey, wawancara dan hasil pre-test, maka dilakukan penyuluhan tentang penyakit tuberkulosis, deteksi dini dan penanganannya, baik dengan obat sintesis maupun dengan obat herbal. Pada kegiatan ini tim mempersiapkan kegiatan penyuluhan dengan mengudang warga yang telah diwawancarai sebelumnya. Kesadaran masyarakat untuk mulai memperbaiki kualitas hidup dengan meningkatkan sistem imun serta mengenali gejala tuberkulosis secara dini dan keinginan untuk memanfaatkan herbal sebagai obat tuberkulosis alami yang aman dan murah, dapat terlihat dari antusiame warga sangat aktif dalam diskusi selama penyuluhan berlangsung.

Penyuluhan kesehatan mengenai penyakit tuberkulosis dilakukan untuk mencegah penyakit tuberkulosis dan mengenalkan pada masyarakat tentang obat-obatan herbal yang diketahui menghambat bakteri penyebab tuberkulosis. Efektivitas penyuluhan dievaluasi dengan melakukan post-test, sehingga dapat diketahui peningkatan pengetahuan tentang penyakit tuberkulosis dan pengobatannya. Peningkatan pengetahuan masyarakat desa Cilayung dapat dilihat dengan jelas pada gambar 1. Jadi dapat disimpulkan bahwa setelah diadakan penyuluhan, tingkat pengetahuan warga menjadi 16,67\% berpengetahuan baik, $56,67 \%$ berpengetahuan cukup, dan $26,67 \%$ berpegetahuan kurang.

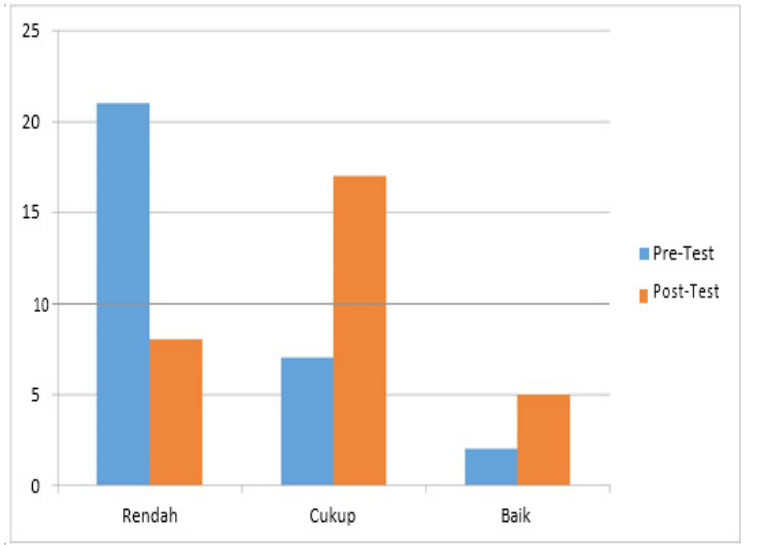

Gambar 1. Perbandingan tingkat pemahaman warga pada pre-test dan post-test 
Peningkatan pengetahuan masyarakat tentang deteksi dini tuberkulosis dan pencegahannya dapat merangsang masyarakat untuk dapat memutus tali penyebaran tuberkulosis, yang dapat dimulai dari diri sendiri dan keluarga serta lingkungan terdekat. Disarankan pula untuk melakukan pemeriksaan dahak sehingga bila ditemukan bakteri TB langsung dilakukan pengobatan. Serta, masyarakat harus menerapkan etika batuk dan bersin yang benar seperti menggunakan tisu saat akan bersin atau batuk lalu segera buang tisu tersebut ke tempat sampah, menutup bagian mulut dan hidung dengan lengan atas, serta selalu jaga kebesihan tangan. Lingkungan di sekitar rumah juga sangat berpengaruh seperti ventilasi dan sanitasi. Rumah harus mendapatkan cahaya matahari yang cukup serta tidak lembab karena bakteri akan lebih cepat berkembang biak di tempat yang lembab dan kotor. Oleh sebab itu, penting juga untuk selalu menjaga kebersihan lingkungan tempat tinggal.

Salah satu upaya pencegahan dan pengobatan lain yang dapat diterapkan oleh masyarakat adalah rutinitas penggunaan herbal untuk tuberkulosis dengan bahan baku yang murah, mudah diperoleh dan mudah diolah, yaitu herba sambiloto (Andrographis paniculata), herba pegagan (Centella asiatica), herba beluntas (Pluchea indica) dan rimpang kencur (Kaempferia galanga). Beberapa herbal yang digunakan dalam kegiatan pengabdian ini dipilih berdasarkan hasil riset dengan dosis in vitro yang terbukti secara ilmiah berkhasiat terhadap bakteri $M$. tuberculosis, sehingga dalam formulasinya digunakan dosis yang lebih besar dua kalinya, yaitu 2g/200 mL. Berdasarkan penelitian, herba sambiloto pada dosis in vitro sebesar $5 \mathrm{mg} / \mathrm{mL}$ mampu menghambat pertumbuhan $M$. tuberculosis H37Rv sebesar 100\% dari total bakteri uji dan mampu menghambat $M$. tuberculosis drug Resistant (MDR) hingga 93.7\% [Radji , et al., 2015]. Daun beluntas pada dosis in vitro $5 \mathrm{mg} /$ $\mathrm{mL}$ mampu menghambat pertumbuhan $M$. tuberculosis H37Rv dan MDR sebesar 100\% [Radji , et al., 2015]. Jadi dapat disimpulkan, daun beluntas berpotensi kuat sebagai anti tuberkulosis alami. Sedangkan herba pegagan memiliki potensi antituberkulosis yang lebih rendah dibandingkan kedua herba tersebut, pada dosis yang sama, herba pegagan mampu menghambat pertumbuhan M. tuberculosis H37Rv sebesar 78.5\% dan 50\% terhadap MDR [Radji, et al., 2015].. Rimpang kencur dalam bentuk ekstrak kental dengan dosis $1 \mathrm{mg} / \mathrm{ml}$ dibuktikan mampu menghambat pertumbuhan M. tuberculosis H37Rv dan isolat $M$. tuberculosis yang resisten terhadap RifampisinStreptomisin sebesar 100\% [Fauziyah PN, et al., 2017].

Di Indonesia, batang, daun dan bunga Andrographis paniculata digunakan secara tradisional untuk pengobatan infeksi saluran pernafasan termasuk tuberkulosis dan ekstrak berair Andrographis paniculata telah digunakan sebagai pengobatan alternatif untuk tuberkulosis dalam perawatan kesehatan primer di Surabaya, Jawa Timur
[Sulistiawati et. al., 2010]. Sedangkan daun beluntas belum pernah secara empiris digunakan untuk pengobatan TBC. Namun diketahui bahwa masing-masing tanaman tersebut mengandung metabolit sekunder yang dapat berperan sebagai antibakteri yaitu flavonoid, alkaloid, tannin, saponin, dan polifenol [Radji , et al., 2015, Arya, 2011; McCarthy and Mahony, 2011]. Mekanisme kerja flavonoid dan beberapa senyawa fenolik sebagai antituberkulosis adalah dengan menghancurkan membran sitoplasma dengan cara melubangi, menghambat sintesis asam nukleat, mengganggu metabolisme energi dengan menghambat nikotinamida dinukleotida adenin ditambah reduktase hidrogen-sitokrom c, dan menghancurkan membran sitoplasma dengan menghasilkan hidrogen peroksida, menghambat sintase ATP, dan menghambat aktivitas katalitik dari DNA topoisomerase I dan II [Askun, 2015]. Dari sejumlah tumbuhan, alkaloid telah dilaporkan berfungsi efektif terhadap M. tuberculosis [Copp, 2003]. Sedangkan pada rimpang kencur terdapat Ethyl cinnamate dan EPMC (Ethyl-p-methoxycinnamate )sebagai unsur utama yang vital dalam ekstrak $K$. galanga, yang diduga memiliki aktivitas antituberkulosis, selain aktivitas anti-radikal, nematicidal, anti-oksidan, antimikroba, antineoplastik, dan anti-inflamasi [Umar 2011; Umar 2014]. EPMC sepertinya dapat menjadi molekul utama untuk mengembangkan obat antituberkulosis baru yang manjur [Fauziyah PN, et al., 2017]. Oleh karena itu, fitokimia dapat menjadi dasar untuk pengembangan obat baru dengan menyediakan farmakofora yang dapat digunakan untuk pengembangan obat baru dengan mekanisme aksi baru. Dengan data penelitian yang jelas, maka masyarakat dapat memanfaatkan bahan herbal tersebut sebagai upaya pencegahan dan pengobatan alami penyakit tuberkulosis. Dengan informasi yang lengkap, mulai dari mengenali gejala tuberkulosis, mendeteksi awal penularan tuberkulosis, cara penyebaran penyakit, pencegahan, dan pengobatan serta teknik pengolahan herbal tuberkulosis, maka diharapkan masyarakat dapat lebih meningkatkan kewaspadaan terhadap penularan tuberkulosis dan mampu memutus rantai penularan tuberkulosis dengan pengobatan yang baik dan benar.

\section{SIMPULAN}

Penyuluhan tentang deteksi dini penyakit tuberkulosis dan pengobatannya dapat dipahami dengan baik oleh warga desa Cilayung dengan bukti adanya peningkatan nilai antara pre-test dan post test. Pengenalan herbal anti tuberkulosis yang mudah diperoleh masyarakat mampu meningkatkan antusiasme masyarakat untuk memanfaatkan herbal tersebut dengan pengetahuan teknik pengolahan herbal yang diperolehnya.

\section{UCAPAN TERIMAKASIH}

Kami mengucapkan terima kasih kepada Pimpinan Universitas Padjadjaran, dan Direktorat Riset dan Pengabdian kepada Masyarakat dan Inovasi Unpad yang 
telah mendanai dan memfasilitasi terlaksananya kegiatan Hibah Internal Pengabdian kepada Masyarakat serta kepada Kepala Desa Cilayung dan seluruh pihak-pihak lain yang telah mendukung pelaksanaan kegiatan PPM integratif ini.

\section{DAFTAR PUSTAKA}

Damma, J., Hallberg K., \& Hellman B. (2009). Genotoxicity of plumbagin and its effects on catechol and NQNO-induced DNA damage in mouse lymphoma cells. Toxicol. In Vitro, 23, 266-271.

Mardiah, W., Mediawati, A.S \& Setyorini, D. (2017). Pencegahan Penularan Infeksi Saluran Pernafasan Akut dan Perawatannya Pada Balita Di Rumah Di kabupaten Pangandaran. Dharmakarya, 6(3), 258261.

Fauziyah, P.N., Sukandar, E.Y., \& Ayuningtyas, D.K. (2017). Combination Effect of Antituberculosis Drugs and Ethanolic Extract of Selected Medicinal Plants against Multi-Drug Resistant Mycobacterium tuberculosis Isolates. Sci. Pharm., 85(14), 2-9.

Morris, S., Bal, H., Suffys, G., Portillo-Gamez, P., Fairchok, L., \& Rouse, M,D. (1995). Molecular Mechanisms of Multiple Drug Resistance in Clinical Isolates of Mycobacterium tuberculosis. J. Infect. Dis., 177, 954-960.

Kemenkes RI. (2015). Rencana Aksi Kegiatan Tahun 2015-2019. Jakarta: Direktorat Bina Produksi dan Distribusi Alat Kesehatan.

Murray, C.J.L., Styblo, K., \& Rouillon, A. (1990). Tuberculosis in Developing Countries: Burden, Intervention and Cost. Bulletin of the International Union against Tuberculosis and Lung Disease. Dis., 65, 6-26.

Radji, M., Kurniati, M., \& Kiranasari, A. (2015). Comparative Antimycobacterial Activity of Some Indonesian Medicinal Plants Against Multi-drug Resistant Mycobacterium tuberculosis. J App Pharm Sci., 5 (01), 19-22.

Retno, A.W. (2011). Patofisiologi, Diagnosis dan Klasifikasi Tuberkulosis. Departemen Ilmu Kedokteran Komunitas, Okupasi dan Keluarga. Jakarta: Fakultas Kedokteran Universitas Indonesia.

Romero, B., Rodríguez, S., Bezos, J., Díaz, R., \& Copano, M. F. (2011). Humans As Source of
Mycobacterium tuberculosis Infection In Cattle, Spain. Emerg Infect. Dis. 17, 2393-2395.

Todar, K. (2012). Mycobacterium tuberculosis and Tuberculosis, In: Todar's Online Textbook of Bacteriology. Madison: Wisconsin.

World Health Organization. (2009). Planning The Development of Human Resources For Health For Implementation of The Stop TB Strategy. Geneva: World Health Organization.

Sulistiawati, Nuswantaro, D., \& Atika. (2010). Enhancement of Tuberculosis Knowledge After Socialization On Tuberculosis And Infusum of Sambiloto (Andrographis paniculata) As Supporting Tuberculosis Treatment Among Participants in Tambak Sari Surabaya. Res Health System Bull., 13(3), 290-296.

Arya V. (2011). A Review On Anti-tubercular Plants. Int J Phar Tech Res.,3, 872-880.

McCarthy, E., \& Mahony, M.O. (2011). What's in a name? Can mullein weed beat TB where modern drugs are failing? Evid-Based Complement and Altern Med.1-7

Kuswinarti, Sitorus., T \& Ruslan,A. (2014). Pemberdayaan Wanita Dengan Peningkatan Pengetahuan Tentang Obat, Pembudidayaan Tanaman Obat Dan Pembuatan Berbagai Sediaan Obat Herbal Untuk Penyakit-Penyakit Umum Di Masyarakat Di Desa Sadasari dan Haurseah Kecamatan Argapura Kabupaten Majalengka. Dharmakarya, 3(1), 2627.

Umar, M.I., Asmawi M.Z., Sadikun, A., Altaf, R., \& Iqbal, M.A. (2011). Phytochemistry and medicinal properties of Kaempferia galanga L. (Zingiberaceae) extracts. Afr. J. Pharm. Pharmacol, 5, 1638-1647.

Umar, M.I., Asmawi, M.Z., Sadikun, A., Majid, A.M., Al-Suede, F.S., \& Hassan, L.E. (2014). Ethylp-methoxycinnamate Isolated From Kaempferia galanga Inhibits Inflammation By Suppressing Interleukin-1, Tumor Necrosis Factor- $\alpha$, And Angiogenesis By Blocking Endothelial Functions. Clinics. 69, 134-144.

Askun, T. (2015). The Significance Of Flavonoids As A Potential Anti-tuberculosis Compounds. RRJPTS., 3, 1-12.

Copp, B.R. (2003). Antimycobacterial Natural Products. Nat Prod Rep., 20, 535-557. 